\title{
Contribution of Parkland Agroforestry Practices to the Rural Community Livelihood and Its Management in Southern Ethiopia
}

\author{
Bayisa Bussa*, Kotola Feleke \\ Department of Natural Resources Management, Bule Hora University, Bule Hora, Ethiopia
}

Email address:

bayisabusa@gmail.com (B. Bussa)

${ }^{*}$ Corresponding author

To cite this article:

Bayisa Bussa, Kotola Feleke. Contribution of Parkland Agroforestry Practices to the Rural Community Livelihood and Its Management in Southern Ethiopia. Humanities and Social Sciences. Vol. 8, No. 4, 2020, pp. 104-111. doi: 10.11648/j.hss.20200804.11

Received: May 30, 2020; Accepted: June 15, 2020; Published: July 4, 2020

\begin{abstract}
Parkland agroforestry which is a system practiced for many local populations is very important for food security, microclimate amelioration, income generation and environmental protection, and is found at different corners of the world, primarily in the semi-arid and sub-humid zones of Africa. It is reported that agroforestry practice is an aged practice in the Ethiopian farming systems of which parkland trees comprise the large part of agricultural landscapes and it is also the most dominant agroforestry practice in the semi-arid and sub-humid zones of Ethiopia. This study was conducted on farmers' parkland Agroforestry practice in Burka Ebela of Bule Hora District Southern Ethiopia which was purposely selected. The objective of this study was to assess contribution of parkland Agroforestry practices to the rural livelihood community. A total of 90 respondents were selected in a systematic sample way from total households of 888 in the study area based on formula used. The data were analyzed using descriptive statistics. The result obtained from the survey showed that, 11 tree species as parkland tree were identified. From those identified tree species the most preferred trees by farmers are: Accia Abyssinica, Accia Albida, Cordia Africana, Croton Macrostachyus Eucalyptus, FicusVasta, Millettia Ferruginea, Podocarpus Falcatus, Rhamnus Priniode and Ricicus Commonis and community used those trees for different purpose such as; for food security, microclimate amelioration, economic benefits, environmental protection, household energy, household utensils, cultural values, traditional medicines and fodder. Challenge to parkland Agroforestry practice in the study area were the exotic tree expansion, plant diseases transmission from old trees to young trees, small land size and lack of replanting. Moreover, these trees are facing challenges like: expansion of cash crops through removal of the parkland trees from the farm area. Even though common management of parkland agroforestry system on the study area was thinning and prunings, more people do not management parkland tree well.
\end{abstract}

Keywords: Parkland, Agro Forestry, Parkland Management, Soil Fertility

\section{Introduction}

A Parkland agroforestry practice is the consistent presence of well grown trees distributed on cultivated or recently tilled fields [1]. Parklands also known as scattered trees in croplands are a very common type of agroforestry system in the tropics on cultivated and recently fallowed lands which is developed as a result of crop cultivation [2]. Agroforestry is the art and science of growing woody and non woody plants together on the same unit of land for arrange of benefit [3]. It is the use of land for combination of agriculture and forestry. In other words it is the practice of growing tree crops or some other fast growing trees along with the main crop. It is also one of the important sustainable land management techniques involving a combination of different agricultural, horticultural, forestry, and livestock practice [4].

The role of agroforestry practices in attaining biodiversity conservation goals has gained accelerating attention in recent years [5]. In parkland practices, the main goal of practicing agroforestry systems is domestication of selected trees for enhancing soil productivity through a combination of 
multipurpose selected trees and food crops on the same farmland [6].

A major reason for practicing agroforestry land use systems is domestication of soil-improving trees for enhancing soil productivity through a combination of selected trees and food crops on the same farm field [7]. Woody species in parkland are often critical components of a farmers' environment being a source of products, environmental services, provide productive, protective and socio-economic, religious roles, maintaining biological diversity to the farmers' livelihood and welfare of the society, especially for smallholder farmers in the developing or underdeveloped world suffering from hunger, poverty, and malnutrition $[2,8,9]$.

It is cost-effective way to enhance food security, while simultaneously contributing to climate change adaptation and mitigation [10-12].

Parkland trees are used to satisfy the needs and demands of the households like: heating, cooking, household utensils, cultural values, provision of pollen and nectar for honey production, construction of houses and handles of farm implements [13], traditional medicines [8], economic benefits, fodder values, employment opportunities and contribute to regional and national economy $[14,15]$.

Parkland agroforestry practices reduce deforestation and pressure on protected forests by providing alternative bioenergy, timber and other forest products from farmers' fields. Moreover, it is used as an ecological corridor allowing species to move between habitats [1].

Parklands reduce the risk of climate change to small holders. It is an established fact that despite the climate changes mitigation (GHG reduction), there is a more pressing need to cope with the impact of climate change (adaptation). So, with this regard, the trees in farmland provide shade for crops found beneath their canopy [2, 16-20]. This is because trees accumulate agroforestry $\mathrm{CO}_{2}$ (which is the most predominant $\mathrm{GHG}$ ) in their biomass and in doing so, not only helps in climate change mitigation but also climate change adaptation (due to the creation of more favorable microclimates on agricultural fields) which is also true to Ethiopian parkland agroforestry systems [21, 22].

Parklands are found dominantly in the semi-arid and subhumid zones of West Africa, but it doesn't mean that they are limited to [8].

Agroforestry parkland system in the semi-arid West Africa, which has supported farmers' life for centuries because of the diversity of plant resources it provides, is under serious threat due to the increasing population pressure on the agricultural lands [23]. Challenges of parkland trees are integral parts of smallholder farming systems in Ethiopia [24]. Despite their substantial economic, social and ecological roles, these trees have received disproportionately little scientific attention [25]. In most of the communities, a common belief is that introducing trees into fields will negatively affect the growth of agricultural crops which is a blind generalization, but in reality, it depends on the species incorporated into the system, the management options applied for, and the like
[26]. In general, tree densities parklands have significantly declined in past decades, especially since the droughts of the 1970 s of Ethiopia, and they are characterized by a predominance of old trees and sometimes alarming lack of regeneration [27].

The other challenge that is significantly hampering the parkland trees is the expansion of exotic trees in the expense of the native ones [28]. Farmers are planting exotic species with important economic roles they play, example; different Eucalyptus species) expansion into the croplands in the expense of the native trees. That is very bad for productivity.

Climate change has also its own negative impact on parkland trees because as climate change it is true the species also change; this, in turn, results in a change of the system. This is because what is a problem to the environment is common affects the parkland agroforestry practices as well [29].

In Ethiopia smallholder farms are under pressure as a result of intensification (includes use of inorganic fertilizer and Eucalyptus plantation for different uses and agroecosystem simplification which could be serious threat to the sustainability of agricultural productivity with negative consequences like: soil erosion, water scarcity and soil fertility decline [30-32].

The identification of species sensitive to recurrent anthropogenic disturbance factors such as bush fire, regular soil tilling, free grazing and plant products harvesting is essential to sound species diversity management in a given regional landscape [33]. Direct sowing of desired species in the parkland could be one of the solutions to the insufficient regeneration of species in the parkland.

To do so, it is crucial to understand management practices from the context of household livelihood strategies and farmers' opinion on the values of trees [34]. Tree management practices are often based on years of experiences of the farmers which need to be understood very carefully and, it is an area where the interaction between trees and peoples is clearly observed [35].

Tree management practices are carried out in order to enhance and secure the trees' function now and in the future and are interdependent with tree utilization which is the final target [36]. The research results of different scholars indicated that tree management practices have dual purposes i.e. reducing light competition with the undergrowth and provision of usable products to the farmers [37-39].

Factors affecting different management decision such as tree planting are mainly related to farming system, household characteristics, rules and regulations imposed by state and community in local or national level and different biophysical circumstances, and tree characteristics [28, 40]. The farm size, farmers age and wealth status are factors influencing tree planting activities as are the environmental conditions influencing actual growth and survival of trees related to specific tree characteristics which is true to Ethiopia as well [28, 41, 42].

There are different alternatives to management practices for agro forestry parklands and the major one constitutes, 
grass mulch application, crop residue application, watering, and coppicing [2, 38, 43-45], pollarding, lopping of side branches [13], pruning [46], plant protection and fertilizing [47], root pruning [48]. Pollarding helps to reduce excessive shading whereas; lopping is to allow the mother trees to grow taller without casting heavy shade over the crops below [49]. Thinning also carried out on parklands when the crowns of two or more adjacent trees started to close and caste heavy shade; however, it is not a common practice. Pruning of parkland agroforestry tree species retained in crop fields is meant for reducing the effect on crops, getting fodder for animals, and collecting wood to be used for fencing and firewood [47].

Many scholars have carried out different researches in different parts of the country about parkland trees of Ethiopia, even though it is not sufficient [50]. Agroforestry practice is an aged practice in Ethiopian farming systems which parkland trees comprise the large part of agricultural landscapes and it is also the most dominant agroforestry practice in the semi-arid and sub-humid zones of Ethiopia [45]. However, very little collected information is available to the stakeholders at different levels. Those different stakeholders are farmers, development agencies and local administration. This is true for our study area as there was no enough structured information about parkland agroforestry in that we intended in parkland agroforestry tree species identification, roles of parkland agroforestry, management options of parkland agroforestry and challenges towards parkland trees as our objectives.

\section{Materials and Methods}

The study area: The study was conducted at Burka Ebela kebele one of 36 kebeles of Bule Hora woreda, West Guji Zone, South Ethiopia. Bule Hora woreda relatively located $467 \mathrm{~km}$ at South of Finfine (Addis Ababa) which is the capital city of Oromia and Ethiopia. It's bounded between Gedeb district in North, Dugdawa district in South, Soda and Karcha in East and Gelana district in West. It has approximately about $14,000 \mathrm{~km}^{2}$ area of land coverage and its astronomical location is $5^{\circ} 38^{\prime} \mathrm{N}$ in latitude and $38^{\circ} 14^{\prime} \mathrm{E}$ in longitude with average elevation of $500-2200 \mathrm{~m}$ a.s.1 [51]. According to the housing and census data appointed the total population of Bule Hora woreda was 266,150 of which 134,603 and 131,547 was male and female respectively. The total human population of the kebeles according to housing and census data appointed the total population of Burka Ebala kebele is 8534 of which 4309 and 4225 male female respectively and 888 households in the kebele with 863 male and 25 female [52].

The climatic condition of Bule Hora is woinadega, semiarid and humid agro ecological zone. The mean annual rainfall is $809 \mathrm{~mm}$ with two peaks April and October. The mean annual maximum temperature and mean annual minimum temperature are $24.5^{\circ} \mathrm{C}$ and $11.56^{\circ} \mathrm{C}$ respectively. The mean maximum temperature for hottest month is $28.3^{\circ} \mathrm{C}$ in February and mean minimum temperature for coldest month was $8.8^{\circ} \mathrm{C}$ in December [53]. The economic activities of this district are mixed farming system which means animal husbandry and cultivation of crops. Some of the dominant crops that are produced in the woreda include maize, teff, barley, wheat, soybean and beans. These crops are used for home consumption. The woreda also produces some cash crops such as coffee, chat, inset and different varieties of fruits.

Study design: Based on the existences of long lived parkland Agroforestry practice and associated challenges the study Kebele was selected purposively with assistance of district agriculture office. A stratified random sampling technique was used for the study considering parkland agroforestry practices. Stratified random sampling is useful method for data collection if the population is heterogeneous [54]. In this method, the entire kebele was divided into villages based on intervention of parkland agroforestry practices using information from guidance at kebele level. From the identified villages, four of them were selected randomly as sampling site. In the identified sampling site, simple random sampling techniques were applied for respondents' selection.

Sample Size and Sampling Techniques: Out of total households 888 , the sample that was selected for this study was 90 individuals (households) based on used formula [55]. In addition to these, the investigators selected 6 respondents for intensive interview (based on experiences and position) and 8 respondents as a focus group discussion from each randomly selected kebele.

Instruments of Data Collection: Both primary and secondary data were collected to accomplish the objective of the study. Secondary data were collected from concerned offices, books, journals and reports. Primary data sources were respondents in the study area that was collected by questionnaires, Focus Group Discussions, field observation and intensive interviews with key informants. Questionnaires were used as a primary instrument to collect primary data from the selected samples households. Investigators prepared open and close ended types of questions for the sample respondents. Since farmers in the study area speak Afaan Oromoo, the questionnaires that were initially prepared in English were translated to Afaan Oromoo.

Data Analysis: Based on the data gathered, descriptive statistical tools like frequency and percentage were used then represented by figures, tables and graphs. The qualitative data collected during focus group discussion, intensive interview and personal observation were analyzed through description, narrating and interpreting the situation contextually.

\section{Results}

\subsection{Identified Tree Species of Parkland Agroforestry at Study Area}

During key informant interview and focus group discussion farmers from the sampled households mentioned 
that for tree species to be incorporated in to farm land, it should be one that sheds its leave before the onset of rain and easily decomposed to increase the soil fertility. Tree species with ever green leave characteristics were kept around the residence, grazing land and farm boundary to provide shade and livestock fodder. The result from the formal survey indicated that shade service for human, livestock and coffee is the best criteria followed by tree species that are conducive for beehives placing. Bee fodder and ability to increase soil fertility are also the other attributes of trees on which the majority of the respondents responded positively.

Table 1. Identified tree species on parkland agroforestry practice in the study area.

\begin{tabular}{llll}
\hline \multirow{2}{*}{ No } & Trees species & & Remark \\
\cline { 2 - 4 } & Local name (by respondents) & Scientific name (flora book) & (by respondents) \\
\hline 1 & Wachu/Bazra girar & Accia Abyssinica & Moderate \\
2 & Gerbi, Derot & Accia Albida & Moderate \\
3 & Diho, Wodesa & Cordia Africana & Low \\
4 & Mokonisa/Bakanissa & Croton Macrostachyus & Moderate \\
5 & bahir zaf & Eucalyptus & Low \\
6 & garbi & Faidherbia albida & Moderate \\
7 & Kilxu & FicusVasta & Low \\
8 & Warka & Millettia Ferruginea & Rore \\
9 & Birbirsa & Podocarpus Falcatus & Moderate \\
10 & Gesho & Rhamnus Priniode & Rare \\
11 & Qobo & Ricicus Commonis & low \\
\hline
\end{tabular}

\subsection{Role of Parkland Agroforestry to Rural Livelihood}

\subsubsection{Social-economic Importance of Parkland Agroforestry for Rural Livelihood}

The highest numbers of respondents $35.5 \%$ were used for food security and the lowest numbers of respondents $6.7 \%$ were used for medicine purpose. The increased income source and food security values of parkland Agroforestry trees for farmers had positive impression on their living standards. This study shown that most of the farmers were used the tree for food security and energy supply and these have great impact on parkland trees. Few of them were used for medicine purpose and for income sources in ascending order (table 2).

Table 2. Contribution of parkland Agroforestry for rural livelihood.

\begin{tabular}{lll}
\hline Socio -economic importance & Frequency & Percentage (\%) \\
\hline Diversified income source & 10 & 11.1 \\
Fodder and animal feed & 15 & 16.7 \\
Food security & 32 & 35.6 \\
For medicine purpose & 6 & 6.7 \\
Fuel wood/energy supply & 27 & 30.0 \\
Total & 90 & 100.0 \\
\hline
\end{tabular}

\subsubsection{Protection Importance of Agroforestry for Rural Livelihood}

As indicated in the (table 3), $44.4 \%$ of respondents told that the Soil fertility improvement, $33.3 \%$ of respondents told that reducing wind and soil erosion, $12.2 \%$ of respondents told that Provision of shelter and shade and the lowest number of respondents $2.2 \%$ of respondents told that biodiversity improvement. Therefore, the increased protection values of parkland Agroforestry trees for farmers had positive impression on environment. This study shown that most of the farmers were used the tree for Soil fertility improvement and few of them were used for biodiversity improvement.

Table 3. Protection importance of Agroforestry practices in the study area.

\begin{tabular}{llll}
\hline No & Protection importance & Frequency & Percentage (\%) \\
\hline 1 & Biodiversity improvement & 2 & 2.2 \\
2 & Provision of shelter and shade & 11 & 12.2 \\
3 & Reducing wind and soil erosion & 30 & 33.3 \\
4 & Reduction of loss of soil moisture & 3 & 3.3 \\
5 & Soil fertility improvement & 40 & 44.4 \\
6 & Soil stabilization & 4 & 4.4 \\
& Total & 90 & 100.0 \\
\hline
\end{tabular}

\subsubsection{Productive Importance of Parkland Agroforestry for Rural Livelihood}

The highest numbers of respondents $30 \%$ of respondents were used timber production and the lowest numbers of respondents' $7.8 \%$ were used for fast decomposing ability.
The increased productive values of parkland Agroforestry trees for farmers had positive impression on their living standards. As in this study shown that most of the farmers were used the tree for timber product has impact on parkland tree its return to deforestation and changing climate and few 
of them used for bee hives placing which has ecological role naturally. Using parkland trees for different purposes may enhance community to conservation of natural resources in response to future use (table 4).

Table 4. Contribution of parkland agroforestry for rural livelihood.

\begin{tabular}{llll}
\hline No. & Productive importance & Frequency & Percentage (\%) \\
\hline 1 & Fast decomposing ability & 7 & 7.8 \\
2 & Manure or compost & 12 & 13.3 \\
3 & Timber product & 27 & 30.0 \\
4 & Used for bee hives placing & 9 & 10.0 \\
5 & Used for making beehives & 12 & 13.3 \\
6 & Used for shelter and shade & 23 & 25.6 \\
& Total & 90 & 100.0 \\
\hline
\end{tabular}

\subsection{Challenges for the Improvement of Parkland Agroforestry practices}

Respondents stated that the major challenges for the improvement of parkland Agroforestry practice in the study area were lack of replanting $(25.6 \%)$, Exotic tree expansion $(21.1 \%)$, plant diseases transmission from old trees to young trees $(18.9 \%)$ and of followed by small land size $(8.9 \%)$.
Plant diseases transmission from old trees to young trees was need to isolate factors that might special affect the improvement of parkland Agroforestry. Tree planting in studies conducted indicated that the presence of trees on farms significantly increased the income and productivity of the land this is even more important because rural people may be unwilling to grow them (table 5).

Table 5. Challenges of parkland Agroforestry improvement in the study area.

\begin{tabular}{llll}
\hline No & Challenge & Frequency & Percentage \\
\hline 1 & Exotic tree expansion & 19 & 21.1 \\
2 & Lack of extension service & 7 & 7.8 \\
3 & Lack of AF mg.t knowledge & 10 & 11.1 \\
4 & Lack of planting materials & 23 & 25.6 \\
5 & Lack of p roduct marketability & 6 & 6.7 \\
6 & Small land size & 8 & 8.9 \\
7 & Transmission of disease & 17 & 18.9 \\
& Total & 90 & 100.0 \\
\hline
\end{tabular}

\subsection{Parkland Tree Management Practices}

Farmers in the study area have been under taking management practices on the trees they have on their land. $70 \%$ low management, $16.7 \%$ were thinning, and $13.3 \%$ were pruning. The highest number of respondent argued that low management on the existing practice. This has negative impact on the parkland tree. Lower numbers of respondent perceived that thinning and pruning are the tree management practices that have been exercised in the area. As the respondents mentioned that the objectives of employing different tree management practices were to reduce the negative effects between tree-crop interface and tree-animal interface, as well as to get tree products for different uses. Farmers not have the knowledge of different parkland tree management practices but also which tree species require the different set of management practices (table 6).

Table 6. Parkland tree management practice in the study area.

\begin{tabular}{lll}
\hline Management practice & Frequency & Percentage \\
\hline low management & 63 & 70.0 \\
Pruning & 12 & 13.3 \\
Thinning & 15 & 16.7 \\
Total & 90 & 100.0 \\
\hline
\end{tabular}

\section{Discussion}

It was observed that, the farmers of the study area have been practicing scatted tree on their farm. From the total households have been practicing parkland agroforestry practices around and within the forest, whereas few of them have not. The reason that was identified by some of the respondents for not practicing parkland agroforestry practices is due to lack of farm land and being engaged in different activities for their means of livelihood such as selling forest products (in the form of timber and construction materials) and daily laborer. Similarly, the sale of agricultural and tree products, the income of the households who are the owners of the farms could also be increased [24, 33, 49].

Farmers in the study area have been obtaining diversified types of benefits from their parkland agroforestry practices. Means of survival for the prevailing of natural disaster that may cause food insecurity (as a result of less vulnerability of those having diversified types of farming system than having mono-cropping system), Cash income generation, household consumption (energy supply), traditional medicine for both human and livestock diseases are some of the major benefits that people have been acquiring. Others research finding also reported that farmers as a system of an agroforestry, parkland trees are not only used for productive and protective function even if these are theoretically the two fundamental attributes of all agroforestry systems but also for their social, economic and cultural as well as religious functions, commonly known as multipurpose agroforestry systems [2, 12, 56]. Cordia africana uses for shade service (for human, livestock and 
coffee), conduciveness for beehives placing, ability to increase soil fertility, bee fodder, use for construction, fast decomposability, use for bee hives making, having low branch volume (to minimize the intensity of shade) and palatable leaves by animals are the selection criteria that were used by the farmers in the study area for tree species incorporation in to the parkland agroforestry practices.

Farmers of the study area have accumulated knowledge of the parkland agroforestry components. This accumulated knowledge enables them to identify the properties that make woody perennials suitable for incorporation in to parkland agroforestry practices. Therefore, tree species which shade their leaves and easily decomposed were incorporated into farm land as they have the potential to improve soil fertility. Accordingly, Cordia africana and Croton macrostachyus tree species were grown deliberately together with other crop components. Those tree species which have contribution in soil fertility improvement but have negative impact on crop production are normally excluded from the farm land and maintained at the farm boundary and/or homestead for their appropriate socio-economic functions. Thus, Eucalyptus camaldulensis are some the tree species that are excluded from farm land but retained in other place. Our finding agrees with research outcome that in southern Ethiopia Cordia africana has significantly more nutrients in the topsoil underneath its canopy, improves soil fertility, and soil and water conservation $[5,57]$.

The major challenges for the improvement of parkland Agroforestry practice in the study area were the exotic tree expansion, plant diseases transmission from old trees to young trees, small land size and lack of replanting. The exotic tree species (farmers are planting exotic species with important economic roles they play, example; different Eucalyptus species) expansion into the croplands in the expense of the native trees. That is very bad for productivity. Similarly in most of the communities, a common belief is that introducing trees into fields will negatively affect the growth of agricultural crops [26].

From the informal survey (interview and personal observation) it was observed that the parkland tree in the study area was under pressure due to human induced factors. The result from formal survey revealed that there was high destruction of parkland tree as respondents perceived. Whereas, only few of the respondents perceived that there was slight destruction of parkland tree in the study area. Accordingly, many farmers living away from the parkland tree perceived as there was high destruction parkland. In the contrast, there was some reservation from farmers living within the forest to recognize the experience of high. This finding supplemented with other research finding that in Ethiopia smallholder farms are under pressure as a result of intensification (includes use of inorganic fertilizer and Eucalyptus plantation for different uses [32, 58]. Other revealed that agro-ecosystem simplification which could be serious threat to the sustainability of agricultural productivity with negative consequences like: soil erosion, water scarcity and soil fertility decline $[30,31]$.

\section{Conclusion}

Parkland trees which are very common practices are important resources for the production, productivity, conservation of biodiversity and other related benefits that are dependent on the existence of the system. These trees are ranging from native to exotic ones and have different densities per hectare; the tree species vary from place to place depending on factors such as; interest of farmers, land size, agro-climatic condition, characteristics of the species etc. Different but appropriate management of parkland trees is very much needed for the productivity of crops and soils which could be increased by the incorporation of an appropriate use of local biodiversity resources. Parkland trees management is a mechanism of controlling the tree-crop competition in farm fields hence selection and management of the species incorporated influences the success of the system. Elimination/reduction of challenges towards parkland agroforestry practices have positive contributions for the local livelihood in terms of income, crop production, fertility of soil and other benefits for the study area in particular and for the country in general.

\section{Conflict of Interests}

The authors declare that they have no competing interests.

\section{Acknowledgements}

The authors would like to acknowledge Burka Ebala kebele Administration for their support by giving the required information for the research and the local communities who shares us their precious time for interview and in all information giving.

\section{References}

[1] Zewde A. and Nebiyou M. Parkland Agroforestry Practices on Biodiversity Conservation- A Review, 2019.

[2] Raj, J. A., \& Lal, B. S. Agroforestry Theory and Practices. Jodhpur: Scientific Publishers, 2014.

[3] Munroe, J. W., \& Isaac, M. E. N-2-Fixing Trees and the Transfer of Fixed-N for Sustainable Agroforestry, 2014.

[4] Boshier, D. H.; Gordon, J. E.; Barrance, A. J. Prospects for Agro-Ecosystems: Meso american Dry-Forest. Biodiversity Docs/Training/FGR_TG/additional_materials, 2006.

[5] Nair PKR, Gordon AM, Mosquera-Losada MR, Agroforestry In: Jorgensen SE, Fath BD. (Eds.), Ecol. Eng., Encyclopedia Ecol. Vol. 1. Elsevier, Oxford, U.K., 2008; pp. 101-10.

[6] Scales BR, Marsden SJ. Biodiversity in small-scale tropical Agroforestry. A review of species richness and abundance shifts and the factors influencing them. Environ. Conserv., 2008; 35 (2): 160-72.

[7] Kassa H, Gebrehiwet K, Yamoah C. Balanites aegyptiaca, a potential tree for parkland agroforestry systems with sorghum in Northern Ethiopia. J Soil Sci Environ Manage, 2010; 1: 107-114. 
[8] Boffa, J. M. Agroforestry Parklands in Sub-Saharan Africa. FAO Conservation Guide, Rome, 1999.

[9] Schelas J, Greenberg R. Forest Patches in Tropical Landscapes. J Appl Ecol, 1996; 34: 544.

[10] Garrity, D. P.; Akinnifesi, F. K.; Ajayi, O. C.; Weldesemayat, S. G.; Mowo, J. G.; Kalinganire, A.; Larwanou, M.; Bayala, J. Evergreen Agriculture: A robust approach to sustainable food security in Africa. Food Secur. 2010, 2, 197-214.

[11] CBD/Secretariat of the Convention on Biological Diversity. Global Biodiversity Outlook 4. Montreal, 2014; pp. 155.

[12] Lemage B, Legesse A. Management and socioeconomic determinants of woody species diversity in parkland Agroforestry in Tembaro District, Southern Ethiopia. Biodivers. Int. J. 2018; 2 (5): 456-62.

[13] Negash, M. Trees Management and Livelihoods in Gedeo's Agroforests, Ethiopia, 2007.

[14] Abebe, T. Diversity in Homegraden Agroforestry Systems of Southern Ethiopia. PhD Dissertation, Wageningen: Wageningen Agricultural University, 2005. -p. 143.

[15] Muleta D. Assefa F. Nemomissa S. Socioeconomic benefits of shade trees in coffee production systems in Bonga and Yayu Hurumu districts, southwestern Ethiopia, 2011.

[16] Gelaw, A., Singh, B., \& Lal, R. Soil Quality Indices for Evaluating Smallholder Agricultural Land Uses in Northern Ethiopia. Sustainability, 2015.-p. 7, 2322-2337.

[17] Mamo, D., \& Asfaw, Z. Status of Selected Soil Properties under Croton Macrostachyus Tree at Gemechis District, West Hararghe Zone, Oromia, Ethiopia. Journal of Biology, Agriculture, and Healthcare, 2017. -p. 7, 8.

[18] Bayala, J., Sanou, J., Teklehaimanot, Z., Kalinganire, A., \& Ouédraogo, S. J. Parklands for Buffering Climate Risk and Sustaining Agricultural Production, 2014.

[19] Atangana, A., Khasa, D., Chang, S., \& Degrande, A. Tropical Agroforestry. Dordrecht: Springer Dordrecht Heidelberg London New York, 2014. https://doi.org/10.1007/978-94-0077723-1

[20] Tsegu, E. The role of Faidherbia albida tree species in parkland agroforestry and its management in Ethiopia, 2019.

[21] Mulat Y. Indigenous Knowledge Practices in Soil Conservation at Konso People, South western Ethiopia. J AGR ENVIRON SCI 2 (2): 2013. P. 1, 9.

[22] Raj, A. Role of Agroforestry in Climate Change Mitigation, 2016.

[23] Nikiema A. Agroforestry parkland species diversity: Uses and Management in Semi-Arid West Africa (Burkina Faso), Wageningen University, Wageningen, 2005.

[24] Gindaba, J., Rozanov, A., \& Negash, L. Trees on Farms and Their Contribution to Soil Fertility Parameters in Bedessa, Eastern Ethiopia. Biology and Fertility, 2005. -P. 42, 66-71.

[25] Badege, B., \& Abdu, A. Agroforestry and Community Forestry for Rehabilitation of Degraded Watersheds in the Ethiopian Highlands, 2003.

[26] FAO. Advancing Agroforestry on the Policy Agenda: A Guide for Decision-Makers. Agroforestry Working Paper No. 1.
Rome, 2013. -p. 37.

[27] Boffa, J. M. West African Agroforestry Parklands: Keys to Conservation and Sustainable Management. Unasylva, 2000.p. 51, 11-17.

[28] Bongers, G. Dynamics in People-Tree Interactions in Farm Fields; Farmers' Perspectives in Meskan District, Ethiopia, 2010.

[29] Mulhollem, J. Agroforestry Systems May Play Vital Role in Mitigating Climate Change, 2018.

[30] Shiferaw, B., \& Holden, S. T. Policy Instruments for Sustainable Land Management: The Case of Highland Smallholders in Ethiopia, 2000.

[31] Dejene, A. Integrated Natural Resources Management to Enhance Food Security, 2003.

[32] Hadgu, K. M., Garrity, D. P., Mowo, J., \& Sileshi, G. Current Extent of Evergreen Agriculture and Prospects for Improving Food Security, 2009.

[33] Albert Nikeima. Agroforestry parkland species diversity, use and management in semi-arid-wast Africa, Burkina faso. 2005.

[34] Zubair, M., \& Garforth, C. Farm-Level Tree Planting in Pakistan: The Role of Farmers Perceptions and Attitudes. Agroforestry Systems, 2006. -p. 66, 217-229.

[35] Roothaert, R., \& Franzel, S. Farmers' Preferences and Use of Local Fodder Trees and Shrubs in Kenya, 2001.

[36] FDRE. Forest Development, Conservation, and Utilization Proclamation. Proclamation No. 1065/2018, Addis Ababa: Federal Democratic Republic of Ethiopia, 2018.

[37] Arnold, J. E. M., \& Dewees, P. A. Tree Management in Farmer Strategies: Responses to Agricultural Intensification. Oxford: Oxford University Press, 1995.

[38] Nair, P. K. R. An Introduction to Agroforestry. Dordrecht: Kluwer Academic Publisher, 1993.

[39] Schuren, S. H. G., \& Snelder, D. J. Tree Growing on Farms in Northeast Luzon, 2008.

[40] RWEDP. Integrating woodfuel production into agroforestry extention programs in South East Asia. RWEDP Report No. 21. FAO. April 1995, West Java, Indonesia.

[41] De Jong, W. Tree and Forest Management in the Floodplains of the Peruvian Amazon, 2001.

[42] Bannister, M. E., \& Nair, P. K. R. Agroforestry Adoption in Haiti: The Importance of Household and Farm Characteristics. Agroforestry Systems, 2003. P. 57, 149-157.

[43] Tengnas B. Agroforestry extension manual for Kenya. Nairobi: International Centre for Research in Agroforestry. Nairobi, Kenya. 1994; P. 188.

[44] Kilewe AM, Kealey KM, Kebaara KX. Agroforestry Development in Kenya Proceedings of the Second Kenya National Seminar on Agroforestry held in Nairobi, Kenya. 1988.

[45] Kindeya, G. Dryland Agroforestry Strategy for Ethiopia. In The Drylands Agroforestry Workshop (p. 26). Nairobi: ICRAF Headquarters, 2004. 
[46] Gizachew, Z., Tesfaye, A., \& Wassie, H. Ficusvasta L. in Parkland and Agroforestry Practices of Hawassa Zuria District, Southern Ethiopia, 2015.

[47] Guyassa, E., \& Raj, A. J. Assessment of Biodiversity in Cropland Agroforestry and Its Role in Livelihood Development in Dryland Area, 2013.

[48] Bayala, J., Roméo, B. H., \& Sanou, J. Competition and Facilitation Related Factors Impacts on Crop Performance in an Agroforestry Parkland System in Burkina Faso, 2013.

[49] Bekele-Tesemma, A. (Ed.). Profitable Agroforestry Innovations for Eastern Africa, 2007a.

[50] Solomon E. Parkland Agroforestry of Ethiopia; Key to Production, Productivity, Biodiversity Conservation and Climate Change Mitigation, a Review, Open Journal of Forestry, 2018.

[51] Bule Hora Agriculture office. Unpublished report from wereda office, 2019.

[52] Bule Hora Burka Ebela kebele office. Unpublished report, 2019.
[53] Gene, B. climate condition in Bule Hora area. Ethiopia, 2015.

[54] Singh, Ajay S. and Masuku, Micah B. Sampling techniques \& determination of sample size in applied statistics research: an overview, International Journal of Economics, Commerce and Management, Vol. II, United Kingdom, 2014.

[55] Yemane. T. Formula of confidence interval, 1967.

[56] Endale, Y., Abayneh, D., Mekuria, A., \& Catherine, M. Farmland Tree Species Diversity and Spatial Distribution Pattern in Semi-Arid East Shewa, Ethiopia. Perceived Multifunctionality of Agroforestry Trees, 2017.

[57] Asfaw, Z., \& Ågren, G. I. Farmers' Local Knowledge and Topsoil Properties of Agroforestry Practices in Sidama, Southern Ethiopia. Agroforestry Systems, 2007. -p. 71, 35-48. https://doi.org/10.1007/s10457-007-9087-0.

[58] Worede, M. Ethiopian in Situ Conservation. The in Situ Approach (pp. 290-301). London, 1997. 